\title{
Quality Improvement and Time to Lift the Ban on Mobile Phones in Secondary Schools
}

\author{
Zvavahera Promise (Corresponding Author) \\ Reformed Church University Faculty of Commerce \\ E-mail: promisezvavahera59@gmail.com Tel: 263-773-471-703
}

Chigora Farai

Catholic University of Zimbabwe

E-mail: fchigora@yahoo.com Tel: 263-772-886-871

Received: June 26, 2018 Accepted: August 23, 2018 Published: September 10, 2018

doi:10.5296/ijld.v8i3.13625 URL: https://doi.org/10.5296/ijld.v8i3.13625

\begin{abstract}
This study was conducted over three months from March to May 2018, at a time when modern mobile phones possess various functions that are invaluable for learning, teaching and communication purposes. Whilst some countries with a quest to improve quality of education, have embraced the continuously evolving technological capacities of mobile phones for educational purposes, secondary school pupils in Zimbabwe are prohibited from using mobile phones in class as these are viewed to be disruptive rather than useful. This study investigated stakeholders' perceptions of potential utilisation of cell phones by secondary school students as learning tools that enhance quality of education. The sample included 15 secondary schools in Mazowe District. From these, the District Education Officials, headmasters, teachers, pupils and parents were given questionnaires to complete. Validation interviews were conducted for triangulation purposes. The findings revealed strong positive responses in favour of allowing the utilisation of mobile phones as learning tools in Zimbabwean secondary schools although some challenges in the implementation process were cited. These included possibilities of: student distraction in class; cheating; inappropriate video recording of class events and the publication of captured material on social platforms which could be harmful to other learners and the school. The issue of cost of data also came up. The study recommended the removal of the blanket ban on the use of mobile phones; instead, school authorities were encouraged to focus on developing strategies for addressing the implementation challenges cited. It is also critical to make sure that accessible cheap data be made available to learners in secondary schools. Schools in Zimbabwe should form networks so that cheap data is made available by
\end{abstract}


sharing the networks. Schools in Zimbabwe, like institutions of higher learning, are encouraged to embrace the National Research and Education Network (NREN) concept which specialises in internet service provision dedicated to supporting the needs of education in Zimbabwe.

Keywords: Mobile phones, secondary schools, quality improvement

\section{Introduction}

Schools across the globe do not allow students to bring cell phones. However, in some countries there is a programme called ' bring your own device to school' as way of promoting the use of information and communication technology in schools with the view of improving quality of education (Higgins, 2013). Even though there is no law on the use of cell phones in Zimbabwean schools, schools authorities have come up with their own rules and regulations and even though these vary from school to school, the bottom line is that learners are not allowed to bring mobile phones. Most schools authorities feel that cell phones have high changes of disrupting learning and therefore, should not be allowed. If a child is caught with a mobile phone in Zimbabwean schools, the device is confiscated and in some cases, parents are called by the schools' authorities to explain why such things are happening. Contrary to what is happening in schools, the Ministry of Primary and Secondary Education is in support of the use of mobile phones in schools as it is felt that cell phones have the potential of improving quality of education and are here to stay (Mukandatsama, 2015). It has been noted that mobile phones to a larger extend are used for learning and social networking purposes (Twum, 2011). This study therefore, sought to find out if the use of cells in schools have the capacity to improve the quality of education in Zimbabwean secondary schools.

\section{Literature Review}

The Business Online Dictionary defines a mobile phone as a small portable device that has the capacity to work in the same manner as an ordinary phone does. A cell phone however, has more features and can go to the extent of performing most functions which are found in a computer. With a mobile phone, an individual can make calls, go on the internet, take some photos and videos which can be used in the future for various purposes. It has been noted that even though some schools in the United States of America allow the use of cell phones, the Government has admitted that they do not have the appropriate infrastructure and human capacity to support the use of such technologies (Higgins, 2013). In the spirit of improving quality of education in its secondary schools, the Rwandan government is one of the a few countries that have allowed the use of mobile phones in their schools (Etoekleousand \& Ktoridou, 2009). However, both teachers and parents slammed this policy direction as they felt that this could lead to high levels of indiscipline leading to poor performance in class. Mamudu and Oyewo (2015) also agree that the use of cellpohones in schools could lead to mobile bullying and examination malpractices. Contrary to Mamudu and Oyewo (2015), Soyemi, Oloruntoba, and Okafor (2015) in another study that was carried in Nigeria at Ahmadu Bello University, Zaria, it was observed that mobile phones indeed improved the performance of learners at secondary school level. 
Various studies have also shown that cell phones can offer many advantages to schoolchildren and teachers (Dianis, 2004; Gadaleta, 2006; Dianis, 2004; Dyrli, 2004) aver that cell phones help students in doing their homework with ease. Programmes such as "bring your own tech" are common in most high schools in the developed countries. This has allowed students to bring their own gadgets for learning purposes. It has also been noted that teachers and students now use cell phones to do homework and search for new information on the internet without hassles of looking for an internet café (Matt, 2013).

On the other hand, parents argue that children are vulnerable and they would want to know what is happening around their children when they are away from home. Parents are worried about the safety of their children more than anything else is (Dianis et al., 2004). In cases of emergencies, schools authorities can also call for emergency services or parents can come to pick up their children. Galley (2000) submits that children can use cell phones to do their homework especially after school. Dyrli (2004) indicates that in private schools there is a belief that mobile phones can be used for communication purposes between parents and their children. In this assertion, there is no mention of their use for learning purposes. Most private schools in the West allow cell phones in their schools. It has been noted that these schools have put in place guidelines for the use of cell phones. These manuals are also circulated to parents so that they are aware of the schools' requirements. Students also agree to abide by these rules and regulations (Kennedy, 2017). The advent of the cell phone technology has led to m-learning which is perceived to be an important tool through the delivery of learning from any place to students who are an anywhere as long as there is internet connectivity (Wang, Wu, \& Wang, 2009). The authors further submit that acceptance of m-learning by all stakeholders is what is missing. Consensus on the use of m-learning could go a long way in realising that the blanket ban on the use of mobile technology is not the best approach in this modern technology global environment.

It is critical that the country develop a strong educational technology infrastructure and legal frameworks to improve the quality of education. This has to be supported by the National Telecommunications and Information Infrastructure. Mobile phones are just a component of ICT. If schools decide to embrace this technology, they should at least have the following:

Internet connectivity;

- Reliable source of power;

- Policy supporting the integration of ICT in schools;

- Affordable gadgets that support the use of internet (Fakokunde, 2017).

Cell phones are generally cheaper and they are compatible with most modern gadgets compared to laptops and desktop computers. Most parents can now afford to buy cell phones for their children. This is a valuable tool that can enhance the quality of education in high schools. It has been noted that the Presidential Computerisation Programme in Zimbabwe has not spread to the breath and width of the country. Starting on another new ICT project could be expensive for the countryand it is therefore critical to enhance the current running programmes and projects (Nkurunziza \& Ndikumana, 2016). 


\subsection{Educational Benefits}

According to (Walsh, 2013), people cannot run away from the use of cell phones for learning purposes as it has become the norm in most schools and institutions of higher learning. On the other hand, pupils in secondary schools will be preparing to be enrolled in these institutions of higher learning and therefore they should appreciate the use of technology at an early stage. It is therefore critical to prepare students in secondary schools for the future. Technology is driving business globally and schools cannot be an exception. Observations from Walsh (2013) have shown that if mobile phones are well managed in schools, they can make learning exciting, affordable and improve on the quality of results. People should not shun technology but should embrace it to keep abreast with others. It has also been noted that cellphones enhance effective teaching as teachers can exchange notes and google to give latest information to pupils and peers. Teachers featured in an article on Scholastic share the same view that these devices have proven useful in classrooms (National School Safety and Security Services, 2005). Students can improve learning through recording a lecture and then go through it later. Mobile phones also help teachers and students to schedule due dates for assignments and can check these against the electronic calendars on their cell phones. Reminders on important dates on schools' calendars can be set on the cellphones so that the pupil is reminded of the approaching event well in advance. It is estimated that around 774 million people around the world are illiterate and that cell phones can improve the literate rates of these communities with mobile phones. It has been noted that mobile phones are cheaper and more convenient in that most students are now loading electronic books on their mobile phones and this is likely to reduce the problems

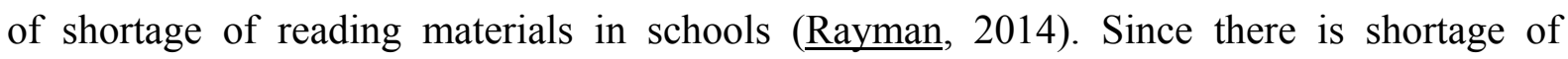
textbooks and other reading materials in Zimbabwe, this can come as a relief to most schools and students.

Rayman (2014) conducted a study on the use of cell phones for reading and writing in the following developing countries; Uganda, Ghana, India, Zimbabwe, Nigeria, Ethiopia, and Pakistan. The findings were that:

- Parents used mobile phones to teach their children how to read and write;

- Woman read more from their cell phones than men;

- Time spent by men and women reading from their cell phones is more than the time they spend reading from books;

- Cell phones have various texts from which users can choose.

Further findings of the same study were that countries could use mobile phones to improve on their population's reading skills. It is therefore critical for governments to invest in these technologies and make them affordable to all the people including poor rural communities (UNESCO, 2011). In another research that was carried by Fakokunde (2017) in Nigeria, it was found that cell phones could be useful for educational purposes even though their ban was a welcome development. The researcher further recommended that it was critical for curriculum developers to include the use of mobile phones so that they become part of the modern learning aids. Leyden (2015) identifies the following as the advantages of using cell phones in 
secondary schools:

- $\quad$ Checking of facts relating to academic work;

- $\quad$ Reading news and current affairs that are related to learning;

- Using mobile phones by teachers to carry out tests and quizzes;

- Taking photos to illustrate work and presentations;

- Using mobile phones as a dictionary;

- Using stopwatch/timer for proper time management;

- $\quad$ Reading eBooks;

- $\quad$ Recording explanation given by teachers for future references;

- Using phones as calculators;

- Accessing resources and materials quickly before examinations;

- Using mobile phones as videos to record experiment for inclusion in projects;

- Using mobile phones as calendar for planning learning activities.

\subsection{Challenges of Using Cell Phones During Lessons}

According to Kevin (2015), the use of cell phones in secondary schools disadvantage learners from poor economic backgrounds thereby leading to uneven access to education. To buttress the same point, Louis-Philippe and Richard (2015) also feel that the use cell phones can detract and even cause health hazards through the continuous exposure to too much light. Omode (2014) feels that as long as there there is no supportive legislation, the use of cell phones becomes a problem. The author feels that the use of cell phones does not add value to the quality of delivery and learning for learners. In a study that was carried out by Kalz et al. (2014) it was noted that even though cell phones were not allowed in schools, the learners indicated they used them to do homework with easy.

It has been found that cell phones can be a disturbing factor especially during live lessons, as most students are likely to be glued to their gadgets. Teachers can also feel disrespected by students due to lack of attention during lessons. Schoolchildren are also likely to misuse cell phones during lessons for instance, taking pictures of other students and then posting them on the social media. Students can also violate the rules and regulations on the use of cell phones. Ringing tones can be pitched high and these can be disturbing if they are not checked by both the teacher and the pupil. Some people feel that students can use cell phones to cheat during examinations. Cell phones can also be used to bully other students or call wrong persons. It is critical for teachers to make sure that laid down rules and regulations are observed by students otherwise there will be chaos in schools. The use of cell phones has created a number of worries such as visiting inappropriate sites, sexting or overuse at the expense of their school work (Higgins, 2013). These are some of the reasons why cell phones are restricted in schools.

\section{Objective of the Study}

The specific objective of this study was to identify the effects of using cell phones for learning purposes in Zimbabwean secondary schools. 


\section{Macrothink}

\section{Research Questions}

- To what extent can the use of cell phones in secondary schools improve the quality of education?

- What are the challenges of using cell phones in secondary schools?

- What recommendations can be made on the use of cell phones in schools?

\section{Methodology}

Qualitative research methodology was applied. The discussion on the research design of this study necessarily leads to the kinds of considerations this study made regarding questions of methodology to be employed in the study. Therefore, in this case, questioners were physically distributed to other respondents and in-depth interviews were done with the key informants which detailed are given below.

\subsection{Population and Sampling}

The population of the study was all, parents, teachers and Ministry of Primary and Secondary Education Senior Officials in Mazowe District. Three focus groups were formed to get views from the parents. Each focus group had fourteen participants. Three Senior Officials from the Ministry and twenty-five teachers from five randomly selected secondary schools in the District became part of the sample. The sample of the study was therefore seventy (70).

\subsection{In-depth Interviews With Key Informants}

Even though the interviews were time-consuming, they became the researcher's main data-gathering method. The researcher used unstructured interviews with key informants who were schools' heads, three senior officials from the Ministry of Primary and Secondary Education on the issues surrounding the use of cell phones in for learning purposes.

\subsection{Data Presentation and Analysis}

Qualitative data were analysed using content analysis. Content analysis was preferred because it can handle large sets of information and provides traceable analysis. The study also dealt with perceptions of the respondents and these are difficulty to quantify. Themes that emerged during data collection were also critical in the presentation and analysis of the data.

\section{Findings}

The findings of this study are presented under two headings:

- Benefits of using mobile phones;

- Challenges raised;

\subsection{Benefits of Using Mobile Phones}

Responses from the key informants revealed that cell phones were good for communication and learning purposes in secondary schools. It was indicated that parents would want know what will be happening around their children when they are not at school. Children can also phone their parents in times of emergencies. It was further submitted that mobile phones had 
the capability of enhancing e-learning and m-learning. The majority of the respondents $(89 \%)$ indicated that internet connectivity was critical as this aided students in their homework. However, it was found that even though all of the schools under the study had electricity, only one school had internet connectivity. This was viewed as a blow to promoting e-learning in rural schools. Forty percent of the parents were also concerned with the high prices of acquiring smart phones. However, it was noted that cell phones were less expensive and convenient to carry around compared to laptops. The Ministry of Primary and Secondary Education officials and most of the teachers submitted that the use of cell phones encouraged independence and open-mindedness in children. Most respondents (96\%) indicated that they had bought their children cell phones and they normally used them at home to do homework, play games and communicate with their friends. It was revealed that some of the pupils uploaded soft copies of textbooks in their mobile phones. On whether, cell phones should be allowed in schools, some parents felt that contemporary education demanded that and let alone theses children were used to cell phones, therefore their use could aid learning. There was consensus that cell phones had various functions such as calculators, cameras, electronic calendars, audio and video recording capabilities that are useful for learning purposes. Someone had this to say "what difference does it make; our children are already using these gadgets at home to do their homework and play intelligent games". This was an acknowledgement from one of the parents that cell phones had become part of their life and would be naïve to ignore that. Ministry officials indicated that both teachers and children should continue to receive training and guidance on the responsible use of cell phones in schools.

\subsection{Challenges Raised}

Even though mobile phones were found to be valuable in improving the quality of education, parents and teacher cited some of the following challenges:

Two dimensions of the cells phones came out of the data namely statistics of leaners and, or, teachers in possession of smart phones and the extent of their use.

- Very few pupils and teachers in Mazowe District confirmed to be possessing a smart phone.

- The few who possessed smart phones used them largely for non-network based functions because of the network connectivity which was near to zero percent as well the expenses involved in buying data bundles so that they could access internet.

Further to the above, a few of the respondents (4\%) indicated that schoolchildren should not be allowed to use cell phones in schools because they divert the children's attention. Teachers and parents raised concerns over the abuse of cell phones by students. Examples such as passing pornographic materials, photos about class events, and bullying other students were given. They further submitted that too much exposure of cell phones to the children could lead to addiction thereby leading to less attention in class. The cost of acquiring smart phones especially for the poor communities like Mazowe was raised. It was noted that some pupils were failing to raise school fees that was said to be in the range of between USD15.00 and 
USD30.00 per term and acquiring a smart phone was a big dream. Most of the respondents (78\%) indicated that the Ministry of Primary and Secondary Education should allow cell phones with basic functions so that children have limited access to these devices. There was consensus from the participants that schoolchildren should be allowed to use cell phones in schools under the supervision of their teachers.

\section{Discussion}

Since we are living in a global world, Zimbabwean schools should follow suit to improve on the quality of education in schools with cell phones. This then implies that it is also possible to introduce them in all schools without many problems. From most parents' perspective it is difficult for some parents from poor backgrounds to afford mobile phones for learning purposes. It is therefore imperative for the Government to come up with a policy that support this initiative through the provision of cheaper gadgets that can be paid over time. Others also indicated that it was a good idea to allow mobile phones in schools as these were likely to improve the quality of results in secondary schools. The fact that most of these students were familiar with these gadgets and how to use them for various purposes was seen as a starting point in introducing mobile technology in secondary schools.

It is critical for teachers to make sure that laid down rules and regulations are followed by learners and teachers otherwise there will be disaster. Mobile phones can perform many functions that are important to schools children. Most cell phones have the ability to performance scientific calculations in mathematics and science subjects. The recording of lessons and field trips can help students understand more when revising their work. Since cell phones are now within the rich of many parents and learners in Zimbabwe, they can use these to go on internet and even load e-books and that reduces the shortage of text books in schools. Mobile phones can be used in mathematics and other science subjects where new information is always coming out. Students can share assignments and other valuable learning materials. This could also be useful to some of the students who might have missed a lesson as they can get the recorded lessons from friends and colleagues. Cell phones, due to their power can be used as sources of entertainment during students' free time. They have very interesting games and these can be relaxing to students after a day's hard work. It should also be noted that students could use cell phones without making calls and blocking unwanted sites.

\section{Recommendations}

Based on the findings of this study, it was observed that mobile phones are here to stay they have become part of people's daily lives. It is against this background that both schools authorities and parents allow pupils to bring cell phones for learning purposes. It is critical for the Ministry of Primary and Secondary Education to come up with guidelines on the use of cell phones in schools. It is also critical to hold stakeholders' meetings on the use of cell phones in schools and agree on the way forward. The Government should avail cheap cell phones with basic functions which can be paid over time.

\section{Conclusion}

It is a reality that cell phone technology is here to stay and it is critical for every sector to 
embrace it in order improve service delivery, productivity, communication and the way business is done. People are now living in a global economy whereby technology drives the way business is done. The removal of the blanket ban on the use of mobile phones is critical and policy makers should develop strategies for addressing the implementation challenges.

\section{References}

Dianis, C. (2004). Local schools happy with cell phone policies. Retrieved September 20, 2005 from http://www.stamfordadvocate.com/news/local/scn-sa-cells3aug24,0,303581.story?coll= stam-news-local-headlines.

Dianis, et al. (2004). Retrieved from http://files.eric.ed.gov/fulltext/EJ847358.pdf

Dyrli, O. E. (2004). Odvard Egil Dyrli on cell phone camera policies. www.DistrictAdminnistration.com.

Etoekleous, N., \& Ktoridou, D. (2009). Investigating Mobile Devices Integration in Higher Education in Cyprus: Faculty Perspective. 3(1), 38-40. Cyprus.

Fakokunde, J. B. (2017). Secondary school students' awareness and use of mobile phones for academic purpose. Educational Journal of the University of Patras UNESCO Chair. 4(1), 83-93.

Gadaleta, T. (2006). Mobile phones and patters. Australian Primary Mathematics Classroom, 11(2), 27-31.

Galley, M. (2000). Districts inclined to hang up on students' cellular phones. Education Week, 19(28), 13.

Higgins, J. (2013). More schools use cellphones as learning tools Retrieved from https://www.google.co.zw/search

http://www.usatoday.com/story/tech/personal/2013/08/07/views-shift-on-cell-phones-in-scho ols $/ 2607381 /$.

Kalz M. et al. (2014). Students' Use of Mobile Phones for School Work. Springer International Publishing Switzerland 2014479, pp. 69-80.

Kennedy, R. (2017). Are Cell Phones Allowed in Schools? Retrieved from https://www.thoughtco.com/are-cell-phones-allowed-in-schools-2774758.

Kevin, M. (2015). Five reasons to ban smart phones in school. Retrieved from http://www.care2.com/causes/5-resons-to-ban-smartphones-in-school.html.

Leyden, A. (2015). 40 uses for smart phones in school. Retrieved from htpp;//www.examtime.com/blog/40-uses-for-smartphones-in-school.

Louis-Philippe, B., \& Richard, M. (2015). Mobile phone bans' improve school exam results'. Retrieved from cep.lse.uc.uk/pubs/download/cp448.pdf.

Mamudu, P. A., \& Oyewo, A. O. (2015). Use of mobile phones for academic purposes by law 
students of Igbinedion University, Okada, Nigeria. International Journal of Library Science, 4(4), 65-72. Rabiu, H., M.

Matt, R. (2013). Digitally Aided Education, Using the Students' Own Electronic Gear. https:/www.nytimes.com/2013/03/23/technology/in-some-schools-students-bring-their-own-t echnology.html.

Merriam-Webster Online Dictionary. (2015). Research. Retrieved April 7, 2015, from http://www.merriam-webster.com/dictionary/research.

Mukandatsama,V.(2015). http://www.manicapost.com/dokora-right-on-cellphones-at-school/.

National School Safety and Security Services. (2005). Cell phone and pager use. Retrieved September 29, 2005 from http://www.schoolsecurity.org/trends/cell_phones.html.

Omode, J. (2014). Awareness of Nigerian students and teachers about potential use of cell phones as a teaching aid. British Journal of Education, Society and Behavioural Science, 4(5), 647-655. https://doi.org/10.9734/BJESBS/2014/7754

Rayman, N. (2014). Cell Phones Could Help Millions in Developing Countries To Read. http://time.com/74584/unesco-study-mobile-phones-book-reading-literacy.

Soyemi, J., Oloruntoba, S. A., \& Okafor, B. (2015). Analysis of mobile phone impact on student academic performance in tertiary institution. International Journal of Emerging Technology and Advanced Engineering, 5(1) 361-367.

Twum, R. (2011). Students' Questionnaire on Mobile Phone Use in Learning.

UNESCO, (2011). Everyone has the right to education. Retrieved from http://unesdoc.unesco.org/images/0021/002127/212715e.pdf.

Walsh, M. (2013). Court Rejects School Search of Student's Cellphone. Retrieved from http://blogs.edweek.org/edweek/school_law/2013/03/court_rejects_school_search_of.html

Wang, Y. S., Wu, M. C., \& Wang, H. Y. (2009). Investigating the determinants and age and gender differences in the acceptance of mobile learning. British Journal of Educational Technology, 40(1), 92-118. https://doi.org/10.1111/j.1467-8535.2007.00809.

\section{Copyright Disclaimer}

Copyright for this article is retained by the author(s), with first publication rights granted to the journal.

This is an open-access article distributed under the terms and conditions of the Creative Commons Attribution license (http://creativecommons.org/licenses/by/4.0/). 